\title{
Determination of Bioethical Perceptions of Gifted Students
}

\author{
Özge Ceylan ${ }^{1}$, Ünsal Umdu Topsakal ${ }^{2}$ \\ ${ }^{1}$ Kartal Bilim ve Sanat Merkezi, İstanbul, Turkey \\ ${ }^{2}$ Faculty of Education, Yıldız Technical University, İstanbul, Turkey \\ Correspondence: Özge Ceylan, Kartal Bilim ve Sanat Merkezi, İstanbul, Turkey.
}

Received: March 26, 2018

doi:10.11114/jets.v6i5.3051

\author{
Accepted: April 9, $2018 \quad$ Online Published: April 9, 2018
}

URL: https://doi.org/10.11114/jets.v6i5.3051

\begin{abstract}
This research was carried out to reveal the bioethical values that special, talented students have about the socioscientific issues that they may encounter in everyday life. Scanning model was used in the research from quantitative research methods. The study's working group is composed of special talented fifth, sixth, seventh, eighth, ninth, and tenth-grade students $(\mathrm{N}=100)$ who have already been diagnosed with a special talent individual in the 2017-2018 academic year and who continue to science and art centers. The Bioethics Value Inventory developed by Kurt (2011) was used as a data collection tool. The inventory consists of five scenarios and contains frequently encountered dilemmas. Scenario issues include active and passive euthanasia, organ donation, GMO products, embryology technologies. In the analysis of the data, descriptive statistics were used for the answers given by the students to the script. Besides, Chi-square test was applied by SPSS package program to determine whether there is a difference in bioethical value and main decision options according to gender, grade level, mother education level and father education level. According to the scenario in the inventory, the students' ethical values (The Utilitarian, The rights, The justice, The virtue, The normative, The theological, preference for natural, The science and technology-based, Belief in Humans' Superiority to Other Living Beings) were calculated by calculating percentages. There are various outcomes in the Chi-square test for each scenario. Despite the fact that private/gifted individuals are few in the society, they need to develop their ethical values, especially when considering the contribution each country can make. For this reason, the ethical values of special, talented individuals should first be identified in their current bioethics, and then the bioethical value education should be given to the privatized programs directed to them. Nowadays, with the emphasis on bioethics education, it is expected that the study will be a source of many kinds of researchers on bioethics education of specially talented children. The study is becoming important in these aspects.
\end{abstract}

Keywords: bioethics education, gifted students, science education, socioscientific issues

\section{Introduction}

When we examine the recent history of the world, we can see that many areas of sociological, economic, technological, ecological, biological, and even moral sense are in change and development. Along with these changes, the needs of the individuals also appear to differ, and the systems of personal values try to adapt to these differences. This situation led to the emergence of different concepts, a conceptual change from the moral ideas to the idea of bioethics began to be defined. The idea of bioethics was put forward by the Dutch scientist Van Rensselaer Potter in the 1970s. However, some scholars regard bioethics as only a part of medicine and others as philosophical ethics and subdiscipline, but they are both inherited from ancient Greeks (Irrazábal, 2015). Garrafa (2006) stated that the historical development of bioethics is the four stages. The first emergence of the concept of bioethics in the 1970s; the latter spreading to Europe and the rest of the world in the 1980s and afterwards; the third phase is the critical stage in the 1990-2005 period and finally the conceptual expansion in 2005 linked to the Unesco Declaration on Bioethics and Human Rights on a daily basis.

Bioethics has been a topic of discussion for a long time in the medical world and has only been associated with medical science. For example, bioethics was expressed by Kushe and Singer (2001) as the area of study of ethical problems in medicine and other biological sciences. Today, it is shown that bioethics has become a more global concept and encompasses not only the human being but also the environment in which all living things and creatures live (Ülman, 2010). Various ethical dilemmas have arisen with the developments experienced especially in biotechnology and the reflection of these developments in daily life. Biotechnology has led to the emergence of different socioscientific issues 
aspects of ethics, there is of acceptable risk levels and the production of useful products (Reiss \& Straughan, 1996). Discussions on the ethical dimension of biotechnology, depending on developments in biotechnology, will continue throughout the 21st century (Özgen, Emiroğlu, Serpen \& Benlioğlu, 2013). Regardless of whether we are positive or negative about these developments, it should be remembered that biotechnology affects the flow of life and that this interaction will increase day by day (Negrinet al., 2007). It is known that individuals are faced with many biological problems when they are thought to be increasingly sensitive to nature and vivacity. As a result, they are expected to decide on moral values that are appropriate to the needs of the society and the age.

When considering the possibility that people of all ages may face these problems individually or indirectly, the education of ethics that will be given to them is gaining importance. It should be emphasized that the special/gifted individuals who have a special place in the social, economic, political and technological development of the country, especially in the education system, should approach these issues. In our country, according to the Ministry of National Education, a gifted child "has been determined by specialists of the subject who perform at a high level regarding if their general or special abilities" (MEB,1991).

The interests of highly talented individuals and the interpretations they make on different topics vary. Due to the interdisciplinary nature of the bioethics issue, for example, combining biology and physics with social and ethical issues, it is thought that superior gifted individuals can be used in putting out differences and making decisions (Bakar, 2010). Teachers emphasize the necessity of contemporary socioscientific discussions in schools (Levinson \& Turner, 2001; Levinson, 2004). A course with bioethics problems will have a broader perspective for student, and their interests and needs will be revealed through the way they deal with issues. Also; these individuals who closely follow the developments in the scientific world need to not only deal with events in an objective or product students, but also with the values we have. Too be able to do these associations, ethical education should be given to students at every level. Ethical education teaches individuals how to balance benefits, risk-takin, and fulfillment of tasks. Moreover, it is necessary to protect the values such as autonomy and justice while balancing them (Macer, 2008:4). Students with advanced moral judgment also have advanced critical negotiating skills (Yazıc1, 2006). Through bioethics education, young people understand that whatever their future career goals, they should be responsible for their lives for science and humanity (Iancu, 2014).

Taking all these considerations into account, bioethics training of individuals, especially children from early ages, is gaining importance. Despite the fact that private/gifted individuals are few in the society, it is necessary to develop their ethical values especially when the countries they live in are thought of the contributions they can make in every field. For this reason, the ethical values of special talented individuals should first be revealed in their current bioethics, and then bioethical education should be included in the programs that are customized for them. No research was conducted to informal current bioethical values in specially trained individuals. The study gains original importance in this respect. It is also thought that this research can be a source and an example in determining the needs when bioethics education is included in the teaching programs applied in our country.

Notably, the following three research questions guided this study:

1. How are the ethical values distributions of student responses for each scenario?

2. Is there a meaningful difference according to students' class, gender, father education level and mother education level in the main decisions of student responses for each scenario?

3. Is there a meaningful difference according to students' class, gender, father education level and mother education level in the ethical values of student responses for each scenario?

\section{Method}

\subsection{Research Method}

In this study, the screening model of quantitative research methods was used to identify the opinions of specially qualified individuals about some current bioethical issues. Screening surveys are surveys of a group of participants whose characteristics such as opinions, talents, interests, skills, attitudes towards a topic or event are determined and are larger than those of other studies (Büyüköztürk, Çakmak, Akgün, Karadeniz, \& Demirel, 2011).

\subsection{Data Collection Tools}

The bioethical value inventory developed by Kurt (2011) was used in the research. This inventory includes scenarios involving ethical dilemmas in environmental ethics, biodiversity, euthanasia, reproductive technologies, organ transplants, and donations. There are options for the scenarios. Each of these options represents a different universal ethics value and includes the bioethical values that participants have. Options are grouped under the headings "I do not 
support,", "I support" and "I am undecided.". For those who do not agree with any of the options, there is an area where they can write their ideas.

The ethical approaches of the scenario responses in the inventory are as follows:

In the $1^{\text {st }}$ scenario, the "I do not support" option is the science and technology-based, the theological, the virtue, the rights and preference for the natural; "Support" option is the justice, the virtue, the utilitarian and the rights; The "undecided" option includes the normative and the ethical justice values.

In the $2^{\text {nd }}$ scenario, the "I do not support" option is the rights, the virtue, the normative, the science and technology-based, the theological and beneficiary; "Support" option is the rights and the utilitarian; The "undecided" option includes the normative ethical values.

In the $3^{\text {rd }}$ scenario, the "I do not support" option is the science and technology-based, the theological, the utilitarian, the normative, the virtue and the rights; "Support" option the virtue and the utilitarian; The "undecided" option includes the normative ethical values.

In the $4^{\text {th }}$ scenario, the "I do not support" option is the rights, the theological, preference for the natural, the virtue and the justice; The "I support" option is the utilitarian and the science and technology-based; The "undecided" option includes the normative ethical values.

In the $5^{\text {th }}$ scenario, "I do not support" option is based on the rights, preference for the natural, the virtue and the theological; The "I support" option is based on the utilitarian, the rights and the science and technology-based; The "undecided" option includes the normative ethical values.

In the work of Samanc1 (2009), explain these ethical approaches as follows:

The Utilitarian Approach: It is important that in the ethical decision-making process, the benefit/loss account is used in the determination of the good and the "maximum" benefit is obtained.

The Rights Approach: The person holds the "rights" in the decision-making process. Believing that the individual has the right to choose with his free will is also considered in this theme.

The Justice Approach: In the ethical decision-making process, the person pre-monitors that the parties are "completely equal.". In the absence of absolute equality, this equation is based on a set of proper measures.

The Virtue Approach: In the process of ethical decision-making, it evaluates actions or situations regarding if their suitability for values such as honesty, courage, and tolerance that they believe contribute to the development of humanity.

The Normative Approach: The person keeps the fact that certain conditions are met in the decision making process. Once these conditions are met, it decides the ethical suitability of the situation or action.

The Theological Approach: It manages relations with other beings, arranges their actions according to religious principles, rule, and values, and keeps these values in front when deciding.

Preference for the Natural: One believes that in the process of ethical decision-making, "the natural one" is better, the human being must be a limit in the intervention of nature, and the natural equilibrium should not be disrupted.

The Science and Technology-Based Approach: It is to keep the advance of scientific advance in the determination of the good while deciding about the ethical problems in nature and society. It is based on this basis to make evaluations.

Belief in Humans' Superiority to Other Living Beings (BHSOLB): By an anthropocentric approach, to believe that man is superior to other beings and to make decisions based on the assumption that other beings are in the service of humankind.

\subsection{Study Group}

The research group constitutes fifth, sixth, seventh, eighth, ninth and tenth-grade students $(\mathrm{N}=100)$ with special talents who continue to Science and Art centers in the 2017-2018 academic year. The percentiles of the students according to class and gender are shown in Figure 1. 


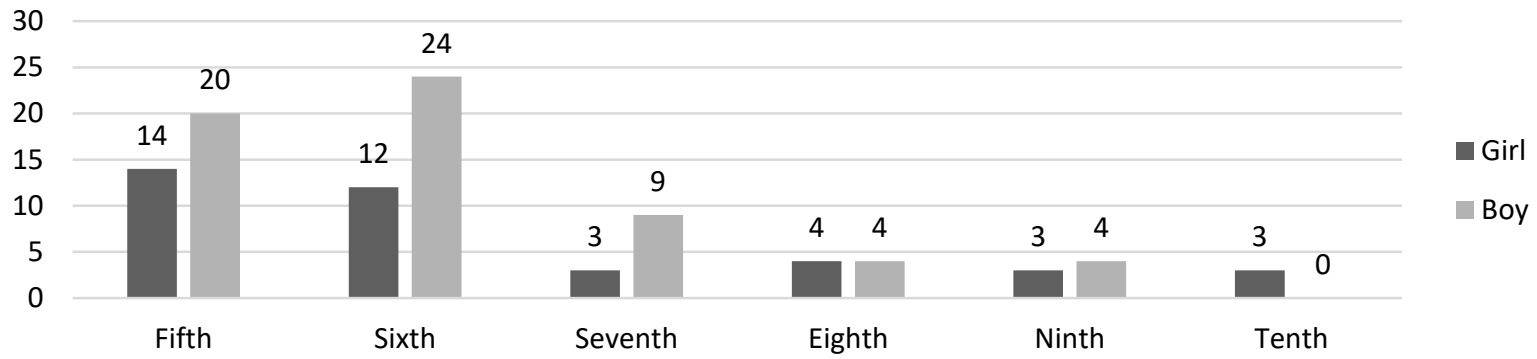

Figure 1. Comparative graphic chart of class level and gender by student

When the data in Figure 1 were examined, 34\% of the students in the study were in the fifth grade, $36 \%$ in the sixth grade, $12 \%$ in the seventh grade, $8 \%$ in the eighth grade, $7 \%$ in the ninth grade and $3 \%$ and $39 \%$ of these students are female and $61 \%$ are male.

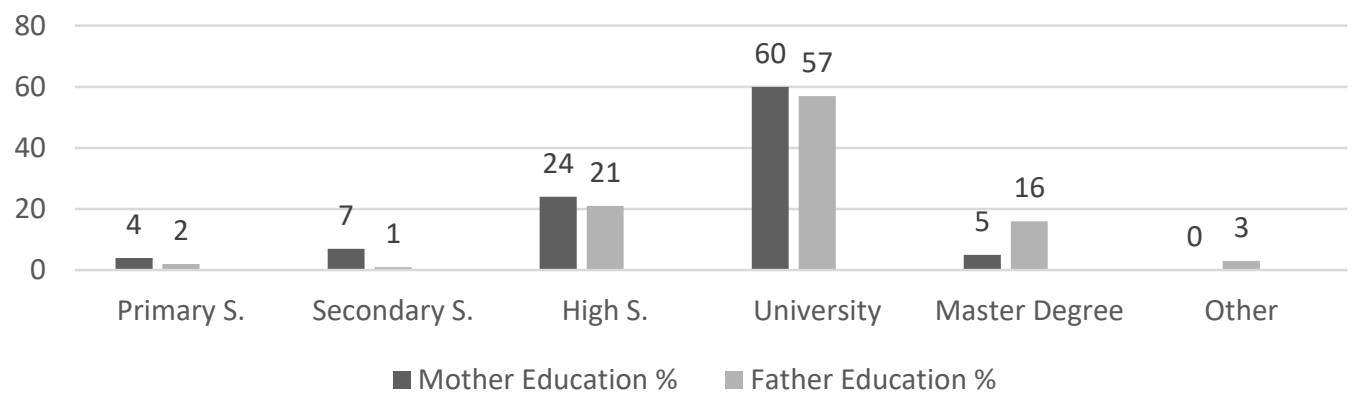

Figure 2. Comparative graphic chart of the educational status' the parents of students

When the data in Fig. 2 is examined, the percentages of education levels of mothers and fathers are seen. Mothers (60\%) and fathers (57\%) appear to have mostly university degrees. And it is seen that the mothers graduated respectively in $24 \%$ high school, $7 \%$ middle school, 5\% master degree and 4\% primary school. It is observed that the fathers graduated in $\% 57$ university, $21 \%$ of the high school, $16 \%$ master degree, $3 \%$ other, $2 \%$ primary school and $1 \%$ secondary school.

\section{Findings}

Findings from the bioethical value inventory were analyzed for descriptive statistics for five scenarios, by gender, parental education status, and class level. There are five questions in the inventory that contain bioethical problems. For each question directed to the students, it is first required to choose one of the main decision options, "I do not support", "I do not support" and "Undecided", and then to choose only one of the sub-options, each of which represents an ethical value, under the main decision options. Accordingly, descriptive statistics for the approach and main decision were drawn from the data obtained from the inventory. The chi-square test was used to analyze whether the ethical approaches to students' main decisions were different according to gender, grade level, mother's education and father's education.

In the first scenario "Mr. Cevdet, suffering from a disease that cannot be treated, attracts unbearable pain. Mr. Cevdet, who has not lost consciousness. Without being under any pressure, wants his doctors to end his life on his own accord. How do you evaluate Mr. Cevdet's decision? Why?" questions were directed, and the answers from the students were evaluated. It is seen in Table 1 students' ethical approach values for the main decisions in the first scenario answers.

Table 1. Students' ethical approach values for the main decisions in the first scenario answers

\begin{tabular}{llllll}
\hline Ethical Approaches & Main Decision (\%) & & \\
\hline & Support & Non Support & Undecided & Own Answer & Total \\
\hline The rights & 12 & 12 & 0 & 0 & 24 \\
The justice & 3 & 0 & 2 & 0 & 5 \\
The virtue & 2 & 18 & 0 & 0 & 20 \\
The normative & 0 & 0 & 17 & 0 & 17 \\
The theological & 0 & 18 & 0 & 0 & 18 \\
Preference for the natural & 0 & 5 & 0 & 0 & 5 \\
The science and technology-based & 0 & 5 & 0 & 0 & 5 \\
No idea & 0 & 0 & 4 & 0 & 4 \\
\hline
\end{tabular}




\begin{tabular}{llllll}
\hline Own answer & 0 & 0 & 0 & 2 & 2 \\
Total & 17 & 58 & 23 & 2 & 100 \\
\hline
\end{tabular}

When Table 1 is examined, it is seen that $58 \%$ of the students do not support Mr. Cevdet's dying judgment and $18 \%$ of the students who do not support have "The virtue" and " The theological " ethical approach. Four of the students stated that they had no idea on this subject, two of them did not participate in any of the options and explained their opinions with their expressions.

The Chi-Square test was conducted to test the students' main decisions in the 1st question to test the significant difference according to classes $\left(\mathrm{X}_{1.1}^{2}\right)$, gender $\left(\mathrm{X}_{1.2}^{2}\right)$, mother education level $\left(\mathrm{X}_{1.3^{2}}{ }^{2}\right)$ and father education level $\left(\mathrm{X}_{1.4}{ }^{2}\right)$. There were no significant differences in other variables $\left(\mathrm{X}_{1.1}{ }^{2}=13,838 ; \mathrm{X}_{1.3}{ }^{2}=11,225 ; \mathrm{X}_{1.4}{ }^{2}=15,010 ; \mathrm{p}>.05\right)$ that only differed in gender -dependent variables $\left(\mathrm{X}_{1.2}{ }^{2}=13,601 ; \mathrm{p}=.004\right)$.

The Chi-Square test was conducted to test the ethical values of the students to significant difference according to classes $\left(\mathrm{X}_{2.1}{ }^{2}\right)$, gender $\left(\mathrm{X}_{2.2}{ }^{2}\right)$, mother education level $\left(\mathrm{X}_{2.3}{ }^{2}\right)$ and father education level $\left(\mathrm{X}_{2.4}{ }^{2}\right)$. The results of the test differ only about to the level of mother education level $\left(\mathrm{X}_{2.3}{ }^{2}=52,981 ; \mathrm{p}=.011\right)$, but no significant difference was observed due to other variables $\left(\mathrm{X}_{2.1}{ }^{2}=45,337 ; \mathrm{X}_{2.2}{ }^{2}=7,263 ; \mathrm{X}_{2.4}^{2}=36,510 ; \mathrm{p}>.05\right)$.

In the second scenario, " Mrs. Handan has lost consciousness, which is not likely to recover and is kept alive by the intensive medical support. Her family decided to close the life support unit, thinking that nothing could be done from now on. How do you rate the family's decision? Why?" questions were directed, and the answers from the students were evaluated. Table 2 shows students' ethical approach values for the main decisions in the second scenario answers.

Table 2. Students' ethical approach values for the main decisions in the second scenario answers

\begin{tabular}{llllll}
\hline Ethical Approaches & \multicolumn{5}{c}{ Main Decision (\%) } \\
\cline { 2 - 6 } The utilitarian & Support & Non Support & Undecided & Own Answer & Total \\
The rights & 6 & 38 & 0 & 0 & 14 \\
The virtue & 0 & 8 & 0 & 0 & 44 \\
The normative & 0 & 7 & 0 & 0 & 8 \\
The theological & 0 & 6 & 12 & 0 & 19 \\
The science and technology-based & 0 & 5 & 0 & 0 & 6 \\
No idea & 0 & 0 & 0 & 0 & 5 \\
Own answer & 0 & 0 & 3 & 0 & 3 \\
Total & 20 & 64 & 0 & 1 & 1 \\
\hline
\end{tabular}

When Table 2 is examined, 64\% of the students who answered the questionnaire did not support the decision to close the life support unit which was given by the family, and $38 \%$ of the students who did not support it seems to have a "The rights" ethical approach. Three of the students stated that they did not have any idea on this issue, one of them did not participate in any options and explained his thoughts with his expressions.

The Chi-Square test was applied to determine whether the main decisions of the students regarding the second question differ according to class $\left(\mathrm{X}_{3.1}{ }^{2}\right)$, gender $\left(\mathrm{X}_{3.2}{ }^{2}\right)$, mother education level $\left(\mathrm{X}_{3.3}{ }^{2}\right)$ and father education level $\left(\mathrm{X}_{3.4}{ }^{2}\right)$. There were no significant differences in the main decisions according to all variables $\left(\mathrm{X}_{3.1}{ }^{2}=22,197 ; \mathrm{X}_{3.2}{ }^{2}=2,130 ; \mathrm{X}_{3.3}{ }^{2}=18,673\right.$; $\left.\mathrm{X}_{3.4}{ }^{2}=11,381 ; \mathrm{p}>.05\right)$.

The Chi-Square test was applied to determine whether the ethical values of the students differ according to the classes $\left(\mathrm{X}_{4.1}{ }^{2}\right)$, gender $\left(\mathrm{X}_{4.2}{ }^{2}\right)$, mother education level $\left(\mathrm{X}_{4.3}{ }^{2}\right)$ and father education level $\left(\mathrm{X}_{4.4}{ }^{2}\right)$. Variables differed only by class level, and there were no significant differences were found in other variables $\left(\mathrm{X}_{4.2}{ }^{2}=7,306 ; \mathrm{X}_{4.3^{2}}=36,144 ; \mathrm{X}_{4.4}{ }^{2}=24,218\right.$; $\mathrm{p}>$.05).

In the third scenario, "Mrs. Safiye has hepatic insufficiency and treatment continues. Organ transplantation is necessary to be able to get healthy. At the same time, Mr. Ekrem was seriously injured in a traffic accident and entered herbal life. Investigations were mad, and it was understood that Ekrem's tissues were suitable for Safiye. The doctors stated that they would be able to transfer Ekrem's liver to Safiye if the family allowed it. How would you decide if you were in the position of Ekrem's family? Why? Three question was directed, and the answers from the students were evaluated. Table 3 shows students' ethical approach values for the main decisions in the third scenario answers.

Table 3. Students' ethical approach values for the main decisions in the third scenario answers.

\begin{tabular}{llllll}
\hline Ethical Approaches & \multicolumn{7}{l}{ Main Decision (\%) } \\
\cline { 2 - 6 } The utilitarian & Support & Non Support & Undecided & Own Answer & Total \\
The rights & 0 & 2 & 0 & 0 & 43 \\
The virtue & 13 & 0 & 0 & 0 & 7 \\
The normative & 0 & 1 & 0 & 0 & 13 \\
The science and technology-based & 0 & 7 & 18 & 0 & 19 \\
\hline
\end{tabular}




\begin{tabular}{llllll}
\hline No idea & 0 & 0 & 5 & 0 & 5 \\
Own answer & 0 & 0 & 0 & 6 & 6 \\
Total & 54 & 17 & 23 & 6 & 100 \\
\hline
\end{tabular}

When the results of the third question are examined, it is seen that $54 \%$ of the students supported the family organ donation decision and $41 \%$ of the supporting students had a "The utilitarian" ethical approach. Five of the students stated that they had no idea of this issue, six of them did not mark any options and explained their thoughts with their expressions.

The Chi-Square test was conducted to determine whether the main decisions of the students regarding the third question differed according to classes $\left(\mathrm{X}_{5.1}{ }^{2}\right)$, gender $\left(\mathrm{X}_{5.2}{ }^{2}\right)$, mother education level $\left(\mathrm{X}_{5.3}{ }^{2}\right)$ and father education level $\left(\mathrm{X}_{5.4}{ }^{2}\right)$. There were no significant differences in main decisions according to all variables $\left(X_{5.1}{ }^{2}=14,501 ; X_{5.2}{ }^{2}=6,949\right.$; $\left.\mathrm{X}_{5.3}{ }^{2}=6,740 ; \mathrm{X}_{5.4}^{2}=9,142 ; \mathrm{p}>.05\right)$.

The Chi-Square test was applied to determine whether the ethical values of the students differ according to the classes $\left(\mathrm{X}_{6.1}{ }^{2}\right)$, gender $\left(\mathrm{X}_{6.2}{ }^{2}\right)$, mother education level $\left(\mathrm{X}_{6.3}{ }^{2}\right)$ and father education level $\left(\mathrm{X}_{6.4}{ }^{2}\right)$. Among the variables, there was only significant difference depending on the gender $\left(\mathrm{X}_{6.2}{ }^{2}=13,798 ; \mathrm{p}=.032\right)$ variable and no significant difference was found in the other variables $\left(\mathrm{X}_{6.1}{ }^{2}=34,878 ; \mathrm{X}_{6.3}{ }^{2}=31,193 ; \mathrm{X}_{6.4}{ }^{2}=28,096 ; \mathrm{p}>.05\right)$.

In the fourth scenario " Farmer Mehmet, who used genetically modified seeds to produce toxins (poisons) against plant insecticides, soon realized that other beneficial beings, such as ladies and butterflies in the environment, also diminished. When he spoke with an agricultural engineer to learn the reason for this, he learned that the toxin produced by the gene transferred to the seeds also affected other living things fed with these seeds and that the number of living things decreased. Farmer Mehmet wants to increase the yield he has gained from the field, on the other hand, he also felt sorry for harming useful living species. What would you do if you were in the position of Farmer Mehmet? Why?" the question was directed, and the answers from the students were analyzed. Table 4 shows students' ethical approach values for the main decisions in the fourth scenario answers.

Table 4. Students' ethical approach values for the main decisions in the fourth scenario answers

\begin{tabular}{|c|c|c|c|c|c|}
\hline Ethical Approaches & & Main Decision & & & \\
\hline & Support & Non Support & Undecided & Own Answer & Total \\
\hline The utilitarian & 0 & 51 & 0 & 0 & 51 \\
\hline The rights & 0 & 14 & 0 & 0 & 14 \\
\hline The justice & 0 & 6 & 0 & 0 & 6 \\
\hline The virtue & 0 & 2 & 0 & 0 & 2 \\
\hline The normative & 0 & 0 & 6 & 0 & 6 \\
\hline The theological & 0 & 4 & 0 & 0 & 4 \\
\hline $\begin{array}{l}\text { Preference for } \\
\text { natural }\end{array}$ & the 0 & 4 & 0 & 0 & 4 \\
\hline $\begin{array}{l}\text { The science } \\
\text { technology-based }\end{array}$ & and 0 & 1 & 1 & 0 & 2 \\
\hline BHSOLB & 0 & 9 & 0 & 0 & 9 \\
\hline Own answer & 0 & 0 & 0 & 2 & 2 \\
\hline Total & 0 & 91 & 7 & 2 & 100 \\
\hline
\end{tabular}

When Table 4 is analyzed, it is seen that $91 \%$ of the students did not support the farmer's decision to use the genetically modified organism (GMO) and 51\% of the unsupported students had a "The utilitarian" ethical approach. None of the students supported using GMO's, two of the students did not mark any options and explained their thoughts in their own words.

The Chi-Square test was conducted to determine whether the main decisions of the students regarding the fourth question differed according to classes $\left(\mathrm{X}_{7.1}{ }^{2}\right)$, gender $\left(\mathrm{X}_{7.2}{ }^{2}\right)$, mother education level $\left(\mathrm{X}_{7.3}\right)$ and father education level $\left(\mathrm{X}_{7.4}{ }^{2}\right)$. According to the analysis results, only the class variable has a significant difference in the main decisions of the students $\left(\mathrm{X}_{7.1}{ }^{2}=26,618 ; \mathrm{p}=.003\right)$, but not in the other variables $\left(\mathrm{X}_{7.2}{ }^{2}=, 434 ; \mathrm{X}_{7.3}{ }^{2}=4,890 ; \mathrm{X}_{7.4}{ }^{2}=5,369 ; \mathrm{p}>.05\right)$.

The Chi-Square test was applied to determine whether the ethical values of the students' significant difference according to the classes $\left(\mathrm{X}_{8.1}{ }^{2}\right)$, gender $\left(\mathrm{X}_{8.2}{ }^{2}\right)$, mother education level $\left(\mathrm{X}_{8.3}{ }^{2}\right)$ and father education level $\left(\mathrm{X}_{8.4}{ }^{2}\right)$. The ethical values of the students differ only according to the level of the classroom, but not in the other variables $\left(\mathrm{X}_{8.2}{ }^{2}=7,791 ; \mathrm{X}_{8.3}{ }^{2}=46,989 ; \mathrm{X}_{8.4}{ }^{2}=24,534 ; \mathrm{p}>.05\right)$.

In the fifth scenario "Emre and Nazlı cannot have children with natural ways. The doctor stated that they could have children with the IVF method. The doctor explained to Emre and Nazl1, who wanted to learn about the method to increase the chances of pregnancy, multiple healthy eggs and embryos resulting from sperm fusion were placed in the mother's womb in the laboratory, and the remaining embryos were also destroyed. Emre and Nazli, who are uncomfortable with the destruction of the remaining embryos, have not been able to decide whether or not to have 
children. What would you do if you were in their place? Why?" the question was directed, and the answers from the students were evaluated. Table 5 shows students' ethical approach values for the main decisions in the fifth scenario answers.

Table 5. Students' ethical approach values for the main decisions in the fifth scenario answers

\begin{tabular}{|c|c|c|c|c|c|}
\hline \multirow[t]{2}{*}{ Ethical Approaches } & \multicolumn{3}{|c|}{ Main Decision (\%) } & \multirow[b]{2}{*}{ Own Answer } & \multirow[b]{2}{*}{ Total } \\
\hline & Support & Non Support & Undecided & & \\
\hline The utilitarian & 11 & 0 & 0 & 0 & 11 \\
\hline The rights & 8 & 16 & 0 & 0 & 24 \\
\hline The virtue & 0 & 9 & 0 & 0 & 9 \\
\hline The normative & 0 & 0 & 29 & 0 & 29 \\
\hline The theological & 0 & 3 & 0 & 0 & 3 \\
\hline Preference for the natural & 0 & 10 & 0 & 0 & 10 \\
\hline The science and technology-based & 6 & 0 & 0 & 0 & 6 \\
\hline No idea & 0 & 0 & 7 & 0 & 7 \\
\hline Own answer & 0 & 0 & 0 & 1 & 1 \\
\hline Total & 25 & 38 & 36 & 1 & 100 \\
\hline
\end{tabular}

When Table 5 was examined, it was seen that $38 \%$ of the students did not support the decision to use reproductive technologies and $36 \%$ were unstable in the answers given to the fifth question. Students who do not support the idea of making children with reproductive technologies seem to have a mostly "The rights" approach, and undecided students often seem to have a "The normative" approach. The seventh of the students explained that they had not an idea on this issue, one of the students did not mark any options and explained his thoughts with his expressions.

The Chi-Square test was conducted to determine whether the main decisions of the students regarding the fourth question differed according to classes $\left(\mathrm{X}_{9.1}{ }^{2}\right)$, gender $\left(\mathrm{X}_{9.2}{ }^{2}\right)$, mother education level $\left(\mathrm{X}_{9.3}\right)$ and father education level $\left(\mathrm{X}_{9.4}{ }^{2}\right)$. There were no significant differences in main decisions according to all variables $\left(\mathrm{X}_{9.1}{ }^{2}=, 19,917 ; \mathrm{X}_{9.2}{ }^{2}=3,295\right.$; $\left.\mathrm{X}_{9.3}{ }^{2}=6,106 ; \mathrm{X}_{9.4}{ }^{2}=14,114 ; \mathrm{p}>.05\right)$.

The Chi-Square test was applied to determine whether the ethical values of the students differ according to the classes $\left(\mathrm{X}_{10.1}{ }^{2}\right)$, gender $\left(\mathrm{X}_{10.2}{ }^{2}\right)$, mother education level $\left(\mathrm{X}_{10.3}{ }^{2}\right)$ and father education level $\left(\mathrm{X}_{10.4}{ }^{2}\right)$. There were no significant differences in main decisions according to all variables $\left(X_{10,1}{ }^{2}=49,483 ; X_{10.2}{ }^{2}=11,244 ; X_{10.3}{ }^{2}=28,546 ; X_{10.4}{ }^{2}=25,514\right.$; $\mathrm{p}>$.05).

\section{Discussion And Conclusion}

In recent years there has been a lot of development in biotechnology. Considering this situation, the students were given scenarios containing socioscientific dilemmas. They will encounter in daily life with this scenarios. In this study, the answers given by the students were examine, and the bioethical values that they have were revealed. The inventory which was developed by Kurt (2011), applied to students consists of five scenarios, including environmental ethics, biodiversity, euthanasia, reproductive technologies, organ transplantation, and donation.

The first scenario concerns the "euthanasia" of bioethics issue. In the face of a disease where the person's treatment is not possible, the opinions of the students were asked depending on whether the person wanted euthanasia. As a result of the analysis, it is seen that $58 \%$ of the students do not support this decision and those who do not support have the ethical approach of "The virtue" by $18 \%$ and "The theological" by $18 \%$. The studies demonstrate the influence of the world's increasing interdependence, globalization, and the priority of human rights discourse (some of the distinctive features of our modern age) on the Islamic tradition (Ghaly, 2013). Along with the main decision answers; gender, class, mother's education level and father's education level, it was found out that only the main decisions differ according to gender. The majority of male students do not support, some of the female students do not support, and some remain undecided. Karahisar (2006) who surveyed with health workers, stated that doctors and nurses did not support the euthanasia decision similar to this study. It is important to emphasize the place of religion in the ethics, as patients' beliefs may affect their decision to refuse treatment, make medical care decisions, or refuse medical treatment for underage children (Post, 1991). When there is a significant difference between the ethical approaches of students and gender, class, mother education level and father education level, the only difference in mother education level is seen. It has been found that female students with a mothers' university degree often have "The rights" ethical approach. In the studies conducted by Kumaş (2005) and Akın (2007), participants mostly expressed euthanasia as a patient right. Two of the students gave their answer. A male $6^{\text {th }}$-grade student said that "I would have wanted to die (suicide) if I would suffer those sufferings.", another a male $7^{\text {th }}$-grade student said that "I will give to Cevdet financial and moral support and evaluate this decision according to the progress of medical technology.".

The second scenario concerns "euthanasia" again, but this time the family's decision to close the life support unit was asked. As a result of the analysis, $64 \%$ of the students did not support the idea of closing the unit, and $38 \%$ of non 
supported students seem to have "The rights" ethical approach. In a study conducted by psychologists against the idea of not supporting the students, the rate of euthanasia decision as a right was found as 85\%. (Özkara, İnceer, Hanc1, Ozan $\&$ Oral, 2004). There was no significant difference in the main decisions according to all variables when the main decision answers and the difference between gender, class, mother education level and father education level were examined. It has been analyzed whether there is a significant difference between the ethical approaches of the students and the gender, class, mother education level and father education level, only a significant difference is found compared to the class levels. In the study conducted by Oğuz et al. (1996), $75.3 \%$ of the physicians looked favorably at closing the life support unit, while the proportion of physicians who can fulfill the euthanasia of a patient was determined as $23.7 \%$. a female $5^{\text {th }}$-grade student said that "Every moment a hope can be bored, and I can save Handan's life.".

The third scenario is related to the organ transplantation. A question was asked of students "If a family member were in herbal life, would you donate his organs to a patient?".As a result of the analysis, 54\% of the students supported organ transplantation. It is seen that $41 \%$ of supporters have a "The utilitarian" ethical approach. Naçar, Çetinkaya, Kanyılmaz, Tokgöz, \& Utaş (2001) stated that medical school students accept $72.3 \%$ of donating their organs after they die. In the study conducted by Kıliç, Koçak, Türker, Gürpınar, \& Gülerik, (2010), this ratio increased to $91.1 \%$. As seen in the studies done, organ donation is supported by the commun it, but active participation is not sufficient. When the main decision answers and the differences between gender, class, mother education level and father education level were examined, no difference was found in the main decisions according to all variables. The significant differences between ethical approaches of students and gender, class, mother education level and father education level are examined. There is an only significant difference in gender variable, and there is no difference in other variables. Akın (2007) explains that girls' acceptance of organ donation differs from that of men in that they have to overcome sacrifice and altruism in their nature and have a traditional life. Six students gave their answer; a male 10th grade student said that "he can give half of the liver because the liver can renew itself very quickly", a male $7^{\text {th }}$ grade student said that "the liver is a self-complementary organ, so they give half", a male 6th grade student said that "wears half the girl", a male 7th grade student said that "If Ekrem has a will for organ donation, I will decide accordingly".

The fourth scenario concerns environmental ethics and biodiversity. Students were asked to think about genetically modified seeds. It has been found that $91 \%$ of students do not support the idea of using other life-threatening seeds and have a 51\% "The utilitarian" approach. Yaman (2011) found that participants mostly had a "The science and technology-based" ethical value in his research through the scenarios for planting GMO products for the benefit of human kind. Dawson and Schibeci (2003) reported that, in contrast to this study, 71-82\% of high school students accepted genetic modification in plants. However, in general studies, it has been found that people do not prefer to use genetically modified products. When the main decision responses and the significant differences between gender, class, mother education level and father education level were examined, only the class variables showed significant differences in the main decisions. A study by Dawson (2007) conducted by students aged 12 to 17 found that students aged 12 to 13 had less positive attitudes toward biotechnology, cloning, and genetically modified foods than older students. It has been examined whether there is a significant difference between ethical approaches of students and gender, class, mother education level, and father education level. There was a significant difference only in the main decisions according to the class variable and not in the other variables. Two students did not participate in any opinion and gave their answers; a female $6^{\text {th }}$ grade student said that "They have the right to live at least as much as we do, everyone is equal, no one can harm anyone", a male $6^{\text {th }}$ grade student said that "I did not harve anything and lived in the city".

The fifth scenario concerns reproduction technologies. It is stated that some embryos are destroyed as a result of in vitro fertilization. Despite this, they were asked about the idea of having children or not utilizing IVF. $38 \%$ of the students did not support it, and 36\% were undecided. It is revealed that the students who do not support have a "The rights" approach and those who are undecided have a "The normative" approach. Akin (2007) studied whether embryos remaining after treatment were to be used in scientific trials and accepted $38.1 \%$ of the participants and $37 \%$ of them did not. Akın (2007) interpreted this situation as opposing the embryos to be seen live and allowing them for informed contribution. Ceylan and Umdu Topsakal (2017) asked a similar question to science teachers and obtained the result that they supported the destruction of embryos, even at close proportions. There was no significant difference according to all variables when the main decision answers between gender, class, mother education level and father education level difference were examined. When there was a significant difference between the ethical approaches of the students and the gender, class, mother education level and father education level, there was no significant difference in all variables. One student did not participate in any opinion and gave her answer; "I do not mind using such a method because it does not harm people.".

As a result, when research problems are taken into consideration, it has been found that students have different values about the ethical problems in current socioscientific issues. In the answers given by the students to the many scenarios, 
it was found that the ethical values were independent of the education level of mother and father, gender or class level. From middle school to undergraduate education, it is important for students at all levels to understand the most important debates in bioethics and to analyze future bioethical debates (Sousa, 2017). Ethical frameworks can provide a robust approach to thinking about teaching and learning in science and technology, strengthen student involvement through links to genuine controversial issues, and empower students to contribute to the reasoned debate about our future (Jones, McKim, \& Reiss, 2010). Integrating bioethics into the curriculum of science education can also increase students 'motivation for science teaching and interaction with science subjects, and improve students' reasoning and justification skills (Chowning, Griswold, Kovarik, \& Collins, 2012).

\section{References}

Akın, H. (2007). The views of the students at the faculty of science and literature and the faculty of education at Çukurova University about the main topics of bioethic (Master's thesis). Çukurova Universtiy Institute of Health Sciences, Adana.

Bakar, E. (2010). The assessment of preservice science teachers' practices and views about bioethics education (Doctoral dissertation). Gazi University Institute of Educational Sciences, Ankara.

Büyüköztürk, Ş., Çakmak, E. K., Akgün, Ö., E., Karadeniz, Ş., \& Demirel, F. (2011). Scientific research methods, 6.

Ceylan, Ö., \& Umdu Topsakal, Ü. (2017). Determination of Bioethical Values Perceptions of Science Teachers, TURKISH STUDIES -International Periodical for the Languages, Literature and History of Turkish or Turkic-, ISSN: 1308-2140, (Prof. Dr. Tahsin Aktaş Armağanı) Volume 12/6, Ankara/Turkey, www.turkishstudies.ne

Chowning, J. T., Griswold, J. C., Kovarik, D. N., \& Collins, L. J. (2012). Fostering critical thinking, reasoning, and argumentation skills through bioethics education. PLoS ONE, 7, e36791. https://doi.org/10.1371/journal.pone.0036791

Dawson, V. (2007). An exploration of high school (12 17-year-old) students' understandings of, and attitudes towards biotechnology processes. Res. Sci. Educ., 37, 59-73. https://doi.org/10.1007/s11165-006-9016-7

Dawson, V. M, \& Schibeci, R. A. (2003). West Australian high school students' attitudes towards biotechnology processes. Journal of Biological Education, 38(1), 7-12. https://doi.org/10.1080/00219266.2003.9655889

Garrafa, V. (2006). Apresentando a bioética. Revista Universitas Face, 2(2), 1-12.

Ghaly, M. (2013). Collective religio-scientific discussions on Islam and HIV/ AIDS: I. Biomedical scientists. Zygon: Journal of Religion and Science, 48, 671-708. https://doi.org/10.1111/zygo.12034

Iancu, M. (2014). Bioethical education in teaching biology. Procedia - Social And Behavioral Sciences, 127(The International Conference Psychology And The Realities Of The Contemporary World - 4th edition-psiworld 2013), 73-77. https://doi.org/10.1016/j.sbspro.2014.03.215

Irrazábal, G. (2015). On the emergence and consolidation of bioethics as a discipline, as seen from a sociological perspective. História, Ciências, Saúde, 22, 4.

Jones, A., McKim, A., \& Reiss, M. (2010). Towards Introducing Ethical Thinking in The Classroom: Beyond Rhetoric edits in Ethics in the Science and Technology Classroom. Netherlands: A New Approach to Teaching and Learning, Sense Publisher.

Karahisar, F. (2006). Views of fatal patients, nurses and physicians on death and euthanasia (Master's thesis). Atatürk University Institute of Health Sciences, Erzurum.

Kılıç, S., Koçak, N., Türker, T., Gürpınar, H., \& Gülerik, D. (2010). Attitudes of female university students about organ donation and factors affecting these attitudes. Gülhane Medical Journal, 52(1), 36-40.

Kuhse, H., \& Singer, P. (2001). What is bioethics?, A historical introduction. In Kuhse and Singer (ed.) A Companion to Bioethics, Oxford: Blackwell, 3-4. https://doi.org/10.1111/b.9780631230199.2001.00002.x

Kumaş, G. (2005). Opinions of nurses about euthanasia who are working in intensive care units at the several hospitals in Adana (Master's thesis). Çukurova University Institute of Health Sciences, Adana.

Kurt, İ. (2011). The development of an instrument used for revealing the values discussions about the ethical issues emerging from the application of biological sciences (Master's thesis). Gazi University Institute of Educational Sciences, Ankara.

Levinson, R. (2004) Teaching bioethics in science: Crossing a bridge too far?, Canadian Journal of Science, Mathematics and Technology Education, 4:3, 353-369. https://doi.org/10.1080/14926150409556619

Levinson, R., \& Turner, S. (2001). Valuable lessons. London: Wellcome Trust. 
Macer, D. R. J. (2008). UNESCO Chair in bioethics. moral games for teaching bioethics. The International Center for Health, Law and Ethics Faculty of Law, University of Haifa.

MEB. (1991). Education report of gifted children. Ankara: Turkish Ministry of National Education

Naçar, M., Çetinkaya, F., Kanyılmaz, D., Tokgöz, B., \& Utaş, C. The attitudes of medical students to organ donation. The Turkish Nephrology, Dialysis and Transplantation Journal, 10(2), 123-128.

Negrin, S., \& Sosa, A. E. (2007). Popular teaching of biotechnology. Biotechnologia Aplicada, 27(1), 58-63.

Oğuz, Y., Şenol, S., Devrimci, Ö. H., Ankazan, M., Özen, A. R., \& Ünal, Ş. (1996). A survey on clinicians' attitudes toward euthanasia. 3P Journal, 4(Ek 3). 43-47.

Özgen, Ö. T., Emiroğlu, H. T., Serpen, A. T., \& Benlioğlu, B. T. (2013). Consumers and genetically modified product groups: a study on perceptions and ethical beliefs. Akdeniz University Faculty of Communication Journal, (20), 236-245.

Özkara E., İnceer B., Hancı İ. H., Ozan, G., \& Oral, G. (2004). Psychologists' Euthanasia Approach. Turkish Journal of Forensic Psychiatry, 1(1), 35-42.

Post, S. (1991). Psychiatry, religious conversion, and medical ethics. Kennedy Institute of Ethics Journal, 1(3), 207-227. https://doi.org/10.1353/ken.0.0023

Reiss, M. J., \& Straughan, R. (1996). Improving nature. The science and ethics of genetic.

Samanc1, K. N. (2009). The development of "bioethical values instrument" for secondary education students within bioethics education (Doctoral dissertation). Gazi University Institute of Educational Sciences, Ankara.

Sousa, C. (2017). Integrating Bioethics in Sciences' curricula using values in science and socio-scientific issues. Multidisciplinary Journal for Education, Social and Technological Sciences, 4(1), 122-134. https://doi.org/10.4995/muse.2017.6481

Ülman, Y. I. (2010). Ethics, bioethics, law: basic concepts and approaches. Acıbadem University Health Sciences Journal, 1(1).

Yazıcı, K. (2006). General view to the values educatıon. Türklük Bilimi Araştırmaları Journal, (19), 499-522.

\section{Copyrights}

Copyright for this article is retained by the author(s), with first publication rights granted to the journal.

This is an open-access article distributed under the terms and conditions of the Creative Commons Attribution license which permits unrestricted use, distribution, and reproduction in any medium, provided the original work is properly cited. 